\title{
Cytotoxicity and genotoxicity evaluation of antidote oxime HI-6 tested on eight cell lines of human and rodent origin
}

\author{
Hana Svobodova, Petr Jost and Rudolf Stetina \\ Faculty of Military Health Sciences, University of Defence, Trebesska 1575, 50001 Hradec Kralove, Czech Republic
}

\begin{abstract}
Oxime HI-6 is an efficient reactivator of the acetylcholinesterase inhibited by organophosphorous nerve agents. In this study we have estimated cytotoxicity of HI- 6 by the colony forming assay and genotoxicity by the comet assay on human and rodent cell lines. IC $\mathrm{I}_{50}$ of $\mathrm{HI}-6$ assessed by the colony forming capacity was $3.59 \mathrm{mM}$ for HeLa cells and $5.18 \mathrm{mM}$ for a mouse cell line L929. Small difference in cytotoxicity was found among other cell lines tested: $\mathrm{IC}_{50}$ was $1.61 \mathrm{mM}$ for human A549 cells, $1.14 \mathrm{mM}$ for UROtse line, $1.96 \mathrm{mM}$ and $1.71 \mathrm{mM}$ for Chinese hamster cells AA8 and UV-20, respectively. The A549 cell viability measured with the MTT test was 5 times decreased comparing 2 and 24 hours of HI- 6 oxime treatment. The $5 \mathrm{mM} \mathrm{HI}-6$ concentration reduced the viability within 2 hours to $95 \%$ only, however, it induced a significant number of DNA breaks in mouse cells L929, and also in human UROtse and HepG2 cells. 1- $\beta$-D-arabinofuranosylcytosine $\left(10^{-4} \mathrm{M}\right)$ and hydroxyurea $\left(10^{-2} \mathrm{M}\right)$, supplemented to the cultivation medium, did not cause any significant accumulation of DNA breaks during treatment, which indicated that the nucleotide excision repair was not acting on the induced DNA damage.
\end{abstract}

Key words: Oxime - Reactivator - Cytotoxicity - Genotoxicity - DNA damage

Abbreviations: AraC, 1- $\beta$-D-arabinofuranosylcytosine; BER, base excision repair; HI-6, ((1-(((4aminocarbonyl)pyridino)methoxy)methyl)-2-(hydroxyimino)-methyl)-pyridinium dichloride monohydrate); HU, hydroxyurea; NER, nucleotide excision repair; MTT, 3-(4,5- dimethylthiazole)2,5-diphenyltetraazolium bromide; PBS, phosphate buffered saline; SSB, single strand breaks.

\section{Introduction}

Standard antidotal therapy against organophosphorous anticholinesterase compounds includes the cholinergic drug, atropine, and acetylcholinesterase $(\mathrm{AChE})$ reactivating agent. HI-6 oxime ((1-(((4-aminocarbonyl)pyridino)methoxy) methyl)-2-(hydroxyimino)-methyl)-pyridinium dichloride monohydrate) is the most effective AChE reactivator with known mechanism of action reactivating organophosphorus inhibited AChE (Cassel et al. 1997). Although the pharmacological profile of HI-6 has been extensively studied, incomparably less data has been published concerning to its preclinical toxicology.

Correspondence to: Rudolf Stetina, Faculty of Military Health Sciences, University of Defence, Trebesska 1575, Hradec Kralove, 50001, Czech Republic

E-mail: r.stetina@tiscali.cz
So far we have not enough information about HI-6 cytotoxicity and genotoxicity. As it was published earlier, HI-6 was not genotoxic using tests on Salmonella typhimurium, mouse lymphoma and Chinese hamster ovary (CHO) cells, both with and without metabolic activation (Putman et al. 1996). In vivo clastogenicity evaluation on rats was also negative, however, HI-6 induced significant amount of chromosome aberrations in vitro in CHO cells. Since then Čalić et al. (2006) has compared cytotoxicity of different oximes (including HI-6) by measuring the metabolic function of mitochondrial succinate dehydrogenase activity of the living cells (MTT test). As the maximal oxime concentration used by them was 0.8 $\mathrm{mM}$ (without cytotoxic effect) the cytotoxic effect could not be evaluated. Also Radić et al. (2007) studied cytotoxicity and genotoxicity of HI-6 in vitro. Authors did not find any significant genotoxic effect of HI-6 on human lymphocytes treated in vitro and measured by induction of chromosome aberrations or micronuclei and also by the alkaline comet 
assay. However, the highest concentration tested was only $0.4 \mathrm{mM}$. Similarly, to studies in vitro, HI-6 administered in vivo to rats did not induce any significant genotoxicity as measured by the induction of micronuclei in peripheral blood leukocytes and by the comet assay in peripheral leukocytes, hepatocytes and brain cells (Vrdoljak et al. 2009).

The objective of the present study was to estimate in vitro cytotoxicity and possible genotoxicity of HI-6 in different human and rodent cell lines using the colony forming assay or the MTT test and the single cell gel electrophoresis (SCGE). We have used both primary human cells (embryonic lung fibroblasts), immortalized (human UROtsa; Rossi et al. 2001) and malignant (HeLa, A549, HepG2) cell lines. The advantage of HepG2 cells using in genotoxicity testing is inducibility and expression of various phase I and phase II enzymes (Knasmüller et al. 1998). Due to the presence of enzymes relevant for xenobiotics metabolism HepG2 cells are favoured for cytotoxicity and genotoxicity assays. They reflect more adequately possible hazardous effects of xenobiotics rather than bacteria or metabolically incompetent mammalian cells such as $\mathrm{CHO}, \mathrm{HeLa}$, or another cell lines which require an exogenous metabolic system for the activation of genotoxicants. Further we used mouse cell line L929, Chinese hamster ovary cell line AA8 and the UV-20 line, a mutant derived from AA8 deficient in the ERCC1 gene coding a nuclease playing essential role in the nucleotide excision repair (NER) (Thompson et al. 1981).

\section{Materials and Methods}

\section{Chemicals}

HI-6 dichloride was synthesized at the Department of Toxicology of the Faculty of Military Health Sciences, Hradec Kralove, Czech Republic. Its purity was $99.5 \%$, as analysed by HPLC technique. It was kept at room temperature and dissolved and diluted in sterile phosphate buffered saline (PBS) immediately before use to the concentration 10 times higher than was the final concentration in medium. HI-6 was added to the cell culture medium for the time interval indicated in results.

\section{Cell lines}

Human HeLa cells, A549 human lung carcinoma cell line (obtained from the European Collection of Cell Culture, Sigma-Aldrich, Prague, Czech Republic), human embryonic lung fibroblasts (SEVAC, Prague), UROtsa - normal urothelial cells (Rossi et al. 2001) and rodent cultures L929 (Eur. Cell Collect.) were cultured in MEM medium supplemented with $10 \%$ of bovine foetal serum (FBS; BioTech, Prague, Czech Republic). HepG2 cells (human epithelial hepatocel- lular carcinoma) were cultured in Williams medium $\mathrm{E}+$ $10 \%$ FBS. The AA8 line of Chinese hamster ovary cells and their mutant UV-20 were cultured in Dulbecco MEM alfa + $6 \%$ FBS. HeLa, HepG2, AA8 and UV-20 cells were obtained from Prof. Andrew Collins (University of Oslo, Norway). Cell line isolated from a primary culture of human urothelium was obtained from Prof. Gunnar Tobin (University of Göteborg, Sweden).

\section{Colony forming assay}

Two hundred cells (800 in the case of UROtse) were plated per each $40 \mathrm{~mm}$ petri dish (TPP) in $1.5 \mathrm{ml}$ of culture medium ( $37^{\circ} \mathrm{C}, 5 \% \mathrm{CO}_{2}, 85 \%$ humidity) and next day HI- 6 dissolved and diluted in PBS to the concentration 10 times higher than used was supplemented and incubated for 24 hours. After the HI- 6 treatment medium was changed and dishes incubated for 7 days. Colonies were fixed with methanol : acetic acid $(3: 1)$, stained with Giemsa and counted. Two dishes were used per experimental sample. Results are presented as percent of colonies formed in control dishes without HI-6 treatment. Each experiment was repeated 2-4 times. $\mathrm{IC}_{50}$ were calculated using probit-logaritmic method (Litchfield and Wilcoxon 1949).

\section{Cell viability assay (MTT test)}

The standard 3-(4,5-dimethylthiazole)-2,5-diphenyltetraazolium bromide (MTT) assay procedure was used for cytotoxicity evaluation (Trivedi et al. 1990). For this assay we used A-549 lung adenocarcinoma cell line. Cells were plated in 96-well microassay culture plates $\left(7 \times 10^{4}\right.$ cells per well $)$ and incubated overnight at $37^{\circ} \mathrm{C}$ in the $5 \% \mathrm{CO}_{2}$ incubator. $\mathrm{HI}-6$ was dissolved in PBS and added, as described above for the colony forming assay. Control wells were prepared by addition of PBS. Wells containing culture medium without cells were used as blanks. The plates were incubated with HI- 6 for $2,24,48$ and $72 \mathrm{~h}$. Upon completion of the incubation the stock MTT dye solution $\left(10 \mu \mathrm{l}, 5 \mathrm{mg}^{-1}\right)$ was supplemented to each well. After $90 \mathrm{~min}$ incubation, buffer $(100 \mu \mathrm{l})$ containing isopropanol (48\%), $1 \mathrm{M}$ hydrochloric acid (2\%) and triton-x $100(0.05 \%)$ was added to solubilize the MTT formazan. The optical density of each well was then measured on a multi-detection microplate reader (model Synergy 2) at a wavelength of $490 \mathrm{~nm}$. Each experiment was repeated at least four times to get the mean values.

\section{DNA damage assessment - Incubation with DNA synthesis and polymerases inhibitors}

Cells were plated in $40 \mathrm{~mm}$ petri dishes $\left(1.5\right.$ or $2 \times 10^{5}$ cells per dish) in $1.5 \mathrm{ml}$ of the culture medium. The next day different concentrations of HI- 6 were added and cells incu- 
bated for another $2 \mathrm{~h}$. The 1- $\beta$-D-arabinofuranosylcytosine (AraC) in concentration $10^{-4} \mathrm{M}$ and $10^{-2} \mathrm{M}$ hydroxyurea (HU) were added to parallel dishes together with HI-6. AraC inhibits the polymerisation step of nucleotide excision repair NER leaving the repair gaps open. These gaps are detected as true breaks under alkaline conditions (Squires et al. 1986; Erixon and Ahnstrom 1987). After the treatment, cells were detached from the dishes by trypsinization and DNA damage was estimated by the comet assay. The dishes with cells treated with HI-6 in the absence of AraC + HU were divided into two portions and each part was analysed separately, one for single strand breaks (SSB) the other for the presence of oxidized pyrimidines using endonuclease III (see the comet assay below).

\section{Comet assay (single cell gel electrophoresis)}

DNA breaks were analysed using the modified alkaline comet assay combined with a use of endonuclease III treatment (Collins et al. 1996, 1997), which cleaves specifically oxidized pyrimidines and abasic sites in DNA (Doetsch et al. 1987). Briefly, analysed cells are split to two samples, cells of each sample embedded in agarose on a microscope slide and incubated in lysing solution $\left(1 \mathrm{~h}, 4^{\circ} \mathrm{C}\right)$. After this step, one of two parallel slides is left in the lysing solution, while the gel with cells on the other slide is incubated with $40 \mu \mathrm{l}$ of endonuclease III ( $45 \mathrm{~min}$, $37^{\circ} \mathrm{C}$ ). All slides are then placed in electrophoresis tank containing the alkaline buffer and incubated to unwind the DNA $\left(40 \mathrm{~min}, 4^{\circ} \mathrm{C}\right)$. Then the electrophoresis follows $(25 \mathrm{~V}$, $30 \mathrm{~min}, 4^{\circ} \mathrm{C}$ ). Comets were visualized by fluorescence microscopy after the staining with ethidium bromide and image analysis Lucia G (Laboratory Imaging, Prague) was used for the evaluating comet parameters. DNA damage (SSB) is expressed as the percentage of DNA in tail (\% tail DNA). The number of SSB measured in slides incubated with the endonuclease III is a sum of SSB detected without the enzyme treatment plus the number of breaks formed by endonuclease III. According to our calibration of the method by X-ray irradiation published previously (Collins et al. 1996, 2008), the amount of SSB $/ 10^{9}$ daltons of single stranded DNA can be calculated as \% tail DNA $\times$ 0.042 under conditions used in our modification of the method.

\section{Statistics}

For statistical analysis the non-parametrical Mann-Whitney U-test was applied. For testing significance of the HI-6 effect the Kruskal-Walis test was used, the significance of the difference between DNA breaks (\% tail) in controls and treated group were re-tested by Mann-Whitney test using the Sigma Stat 2.03 software.

\section{Results}

\section{Inhibition of colony-forming ability}

The ability of cells to form colonies in the presence of different concentrations of HI- 6 was estimated. Cells were plated in petri dishes and the next day different concentrations of HI- 6 were added to the culture medium and incubated for 24 hours. The grown-up colonies were counted after 7 days. As can be seen in Fig. 1, HI-6 toxicity is quite low up to the $0.6 \mathrm{mM}$ concentration.

From $1.25 \mathrm{mM}$ concentration a colony forming ability is reduced and is completely inhibited by $5 \mathrm{mM}$ concentration

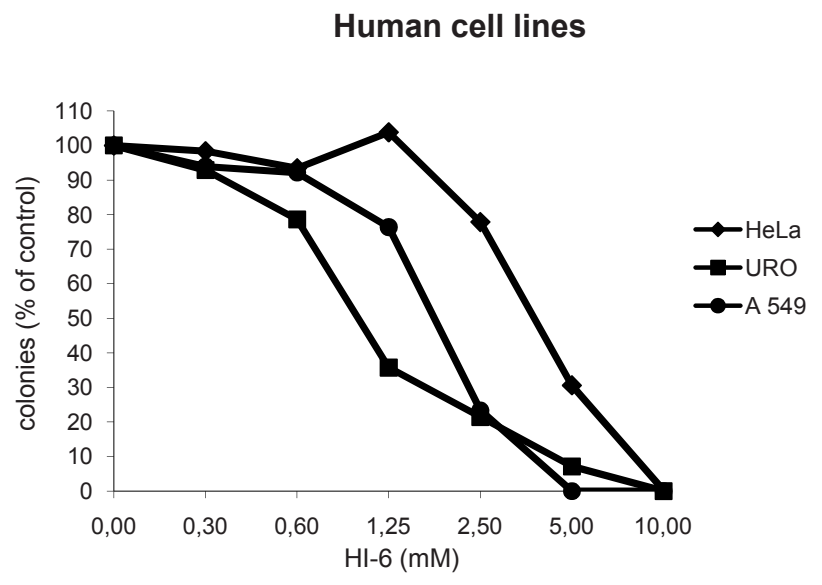

Rodent cell lines

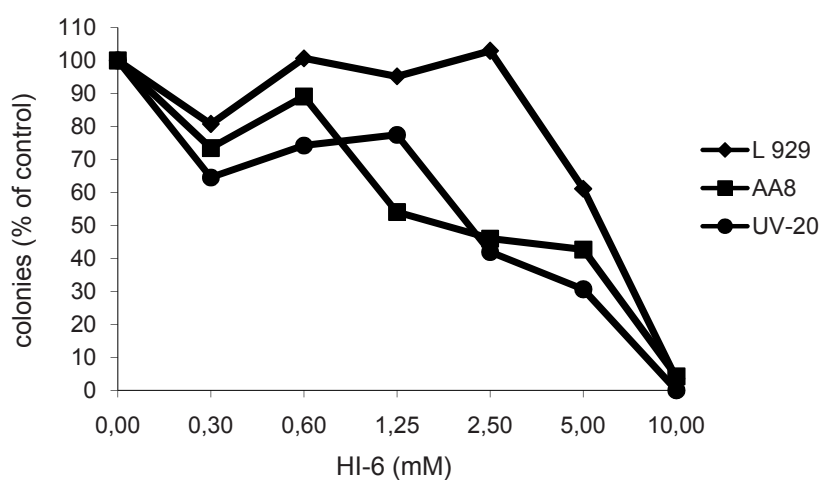

Figure 1. Inhibition of human and rodent cell colony forming ability treated with HI-6. 200 cells (or 800 in the case of UROtse cells) were plated per $40 \mathrm{~mm}$ petri dish in $1.5 \mathrm{ml}$ of medium. The next day the HI-6 oxime was supplemented to medium for $24 \mathrm{~h}$; 2 dishes were used for each experimental sample. Dishes were washed with PBS and incubated in the fresh medium for 7 days. Then colonies were fixed with methanol and stained with Giemsa. Results are presented as means of percent of the number of colonies in control dishes without HI-6 obtained from 2-4 experiments. SD did not exceed $7 \%$ of presented values. 


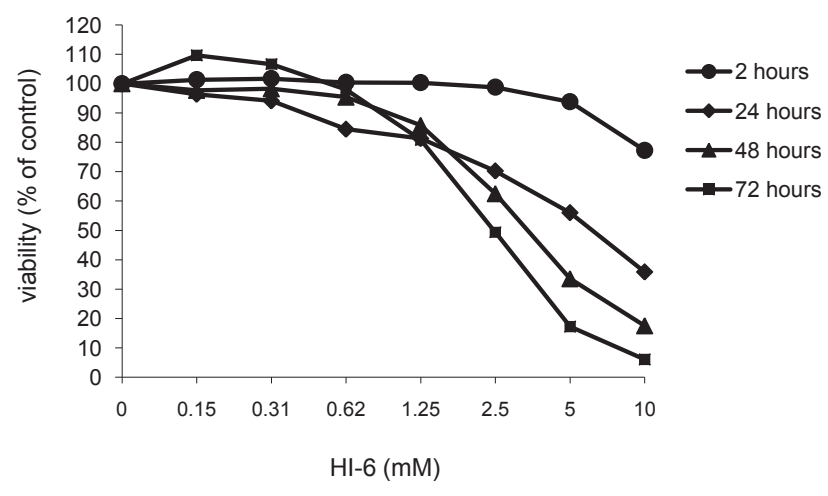

Figure 2. The effect of HI-6 on the viability of A549 cells. Cells plated in 96 -well microassay culture plates $\left(7 \times 10^{4}\right.$ cells per well $)$ were incubated overnight and HI- 6 oxime was supplemented for indicated period of time (2, 24, 48 and $72 \mathrm{~h})$. Then MTT dye solution $\left(10 \mu \mathrm{l}, 5 \mathrm{mg}^{-1}\right)$ was added to each well for $90 \mathrm{~min}$ and the formed formazan was dissolved in buffer $(100 \mu \mathrm{l})$ containing isopropanol (48\%), $1 \mathrm{M}$ hydrochloric acid (2\%) and triton-x 100 $(0.05 \%)$. The optical density was measured at the wavelength of 490 $\mathrm{nm}$ (see Materials and Methods for details). SD did not exceed 5\% of presented values $(n=2)$.

(in the case of most sensitive cells URO and A549) or by 10 $\mathrm{mM}$ concentration of HI-6.

Significant difference in HI-6 toxicity for tested cell lines was found. In Table 1 HI- 6 concentrations causing $50 \%$ inhibition of the colony-forming capacity are presented. Only mouse cell line L929 seems to be more resistant to HI-6, showing $\mathrm{IC}_{50}=5.18 \mathrm{mM}$. HeLa cells exhibited sensitivity between L929 and the rest of cell lines $\left(\mathrm{IC}_{50}=3.59 \mathrm{mM}\right)$. There was found practically no difference among other cell lines tested, when $\mathrm{IC}_{50}$ for A549 cells was $1.61 \mathrm{mM}$, for human urothelial cell line UROtse $1.14 \mathrm{mM}$, and for Chinese hamster cells AA8 $1.96 \mathrm{mM}$, or nucleotide excision repair-deficient mutant cell UV-20 $1.71 \mathrm{mM}$.

Table 1. Concentrations causing 50\% inhibition of colonies after treatment with HI-6 oxime

\begin{tabular}{lcc}
\hline & Cell line & $\mathrm{IC}_{50}(\mathrm{mM})$ \\
\hline \multirow{3}{*}{ rodent } & L959 & 5.18 \\
& AA8 & 1.96 \\
& UV-20 & 1.71 \\
\hline \multirow{3}{*}{ human } & HeLa & 3.59 \\
& A549 & 1.61 \\
& URO & 1.14 \\
\hline
\end{tabular}

For the assay see the legend to Fig. 1. The data represent means from 2-4 experiments. SD did not exceed $7 \%$ of the presented values.

\section{Cell viability (MTT test)}

The HI- 6 effect on viability of A549 cells was measured by the MTT test. A549 cells grown in 96 well microtiter plates were treated with HI- 6 for 2, 24, 48 or $72 \mathrm{~h}$. As can be seen in Fig. 2, viability of A549 cells incubated with HI-6 decreases at concentrations higher than $0.6 \mathrm{mM}$. Similarly to inhibition of colony-forming capacity, a significant decrease of viability was observed in cells treated with $5 \mathrm{mM}$ or 10 $\mathrm{mM}$ concentrations. This decrease of cell viability was timedependent. As an example, viability of cells treated with 2.5 mM HI- 6 decreased from $60 \%$ after 24 h to 55 or $30 \%$ after 48 or 72 h, respectively. On the other hand, after 2 h of treatment viability was only slightly, but insignificantly affected by $5 \mathrm{mM} \mathrm{HI}-6$.

\section{DNA damage induced by HI-6}

DNA damage was evaluated by the comet assay in cell lines after $2 \mathrm{~h}$ of treatment (Fig. 3 and 4). After HI-6 treatment of cells both SSB and oxidative damage to DNA (endonuclease III sensitive sites) were estimated by the comet assay. $10^{-4} \mathrm{M}$ AraC and $10^{-2} \mathrm{M}$ HU were added to parallel cultures together with HI-6. HI-6 did not induce any significant amount of DNA breaks (expressed as \% tail DNA) in A549, or LEP cells. In HeLa cells for $24 \mathrm{~h}$ of treatment with the highest concentration of HI- 6 tested $(10 \mathrm{mM})$ a small increase in the tail DNA up to $30 \%$ was observed. The highest DNA damage (40 to 70\% DNA in tail) induced by HI- 6 was found in UROtse cells, where we have found an increase in tail DNA after $2 \mathrm{~h}$ of cell treatment with concentrations 5 and $10 \mathrm{mM}$, respectively. A significant induction of DNA breaks was scored neither in the $\mathrm{CHO}$ cell subline AA8, nor in its DNA repair-defective mutant UV-20. In contrast to these cells, in the mouse cell line L929 induction of DNA damage was comparable to sensitive URO line. The value $\%$ tail DNA raised within $2 \mathrm{~h}$ of treatment to $50 \%$ in cells treated with $10 \mathrm{mM}$ HI-6. The incubation of cells with the endonuclease III did not show any significant increase of DNA breaks (alkali-labile sites) in any of cell lines used. Similarly, the incubation of cells in the presence of AraC and $\mathrm{HU}$ did not cause any significant accumulation of DNA breaks except of HepG 2 and AA8 cells, where a significant but small increase (by some $25 \%$ tail DNA) was observed.

\section{Discussion}

Cytotoxicity and genotoxicity of HI-6 was previously studied by Putman et al. (1996). In this study a HI-6 dichloride was tested in a battery of assays to measure its potential to induce gene mutations and chromosomal aberrations. No induction of mutations was found using the Salmonella mutagenicity 

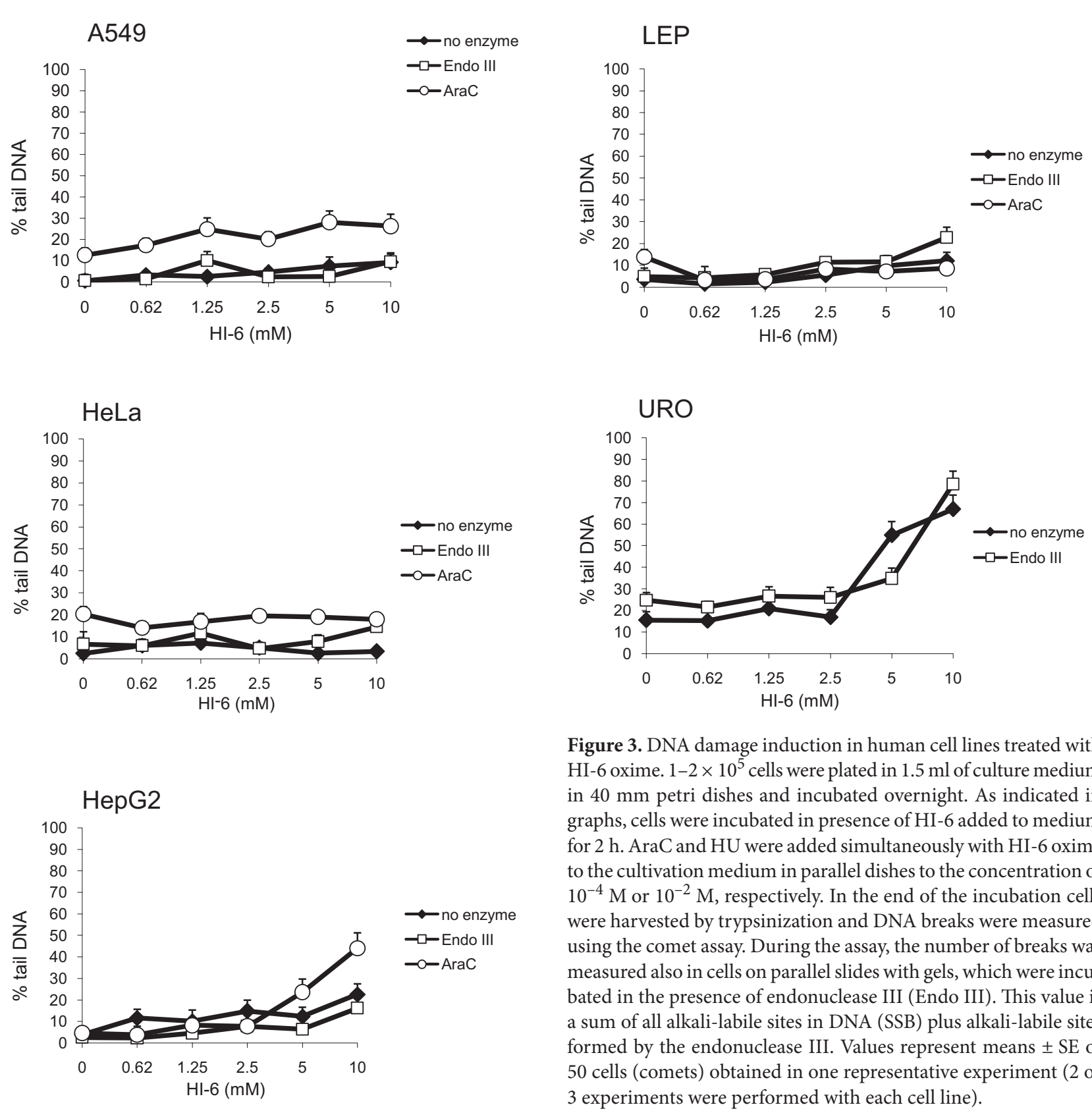

Figure 3. DNA damage induction in human cell lines treated with HI- 6 oxime. $1-2 \times 10^{5}$ cells were plated in $1.5 \mathrm{ml}$ of culture medium in $40 \mathrm{~mm}$ petri dishes and incubated overnight. As indicated in graphs, cells were incubated in presence of HI- 6 added to medium for $2 \mathrm{~h}$. AraC and $\mathrm{HU}$ were added simultaneously with HI- 6 oxime to the cultivation medium in parallel dishes to the concentration of $10^{-4} \mathrm{M}$ or $10^{-2} \mathrm{M}$, respectively. In the end of the incubation cells were harvested by trypsinization and DNA breaks were measured using the comet assay. During the assay, the number of breaks was measured also in cells on parallel slides with gels, which were incubated in the presence of endonuclease III (Endo III). This value is a sum of all alkali-labile sites in DNA (SSB) plus alkali-labile sites formed by the endonuclease III. Values represent means \pm SE of 50 cells (comets) obtained in one representative experiment ( 2 or 3 experiments were performed with each cell line).

and the CHO/HGPRT assays. The mouse lymphoma gene mutation assay was negative as well. As to investigate the HI-6 effects further, clastogenic responses were studied also in vivo by the rat bone marrow metaphase assay. Also in this assay HI-6 showed negative clastogenic responses. However, a dose-dependent increase of chromosome aberrations in $\mathrm{CHO}$ cells and in cultured human peripheral blood lymphocytes treated with HI-6 was observed. The induction of chromosome damage was observed both with and without the cells incubation with microsomal S9 fraction, indicating that most probably not a metabolite, but HI-6 itself was

responsible for the induction of chromosome damage found in the study (Putman et al. 1996). Published results indicate that HI-6 does not induce gene mutations in vitro. Although, it is not clastogenic in vivo, it is clastogenic in vitro. Nevertheless, the concentrations inducing the clastogenic effect in vitro are high $(0.6-2.5 \mathrm{mg} / \mathrm{ml})$ but fare from concentrations achievable in vivo in blood $(100 \mu \mathrm{M})$ or brain $(10 \mu \mathrm{M})$ after the application of potential therapeutic doses (Ecobichon et al. 1996; Cassel et al. 1997).

The valuable information about HI- 6 brought Čalić et al. (2006), who revealed by the MTT assay that HI-6 (as well as 

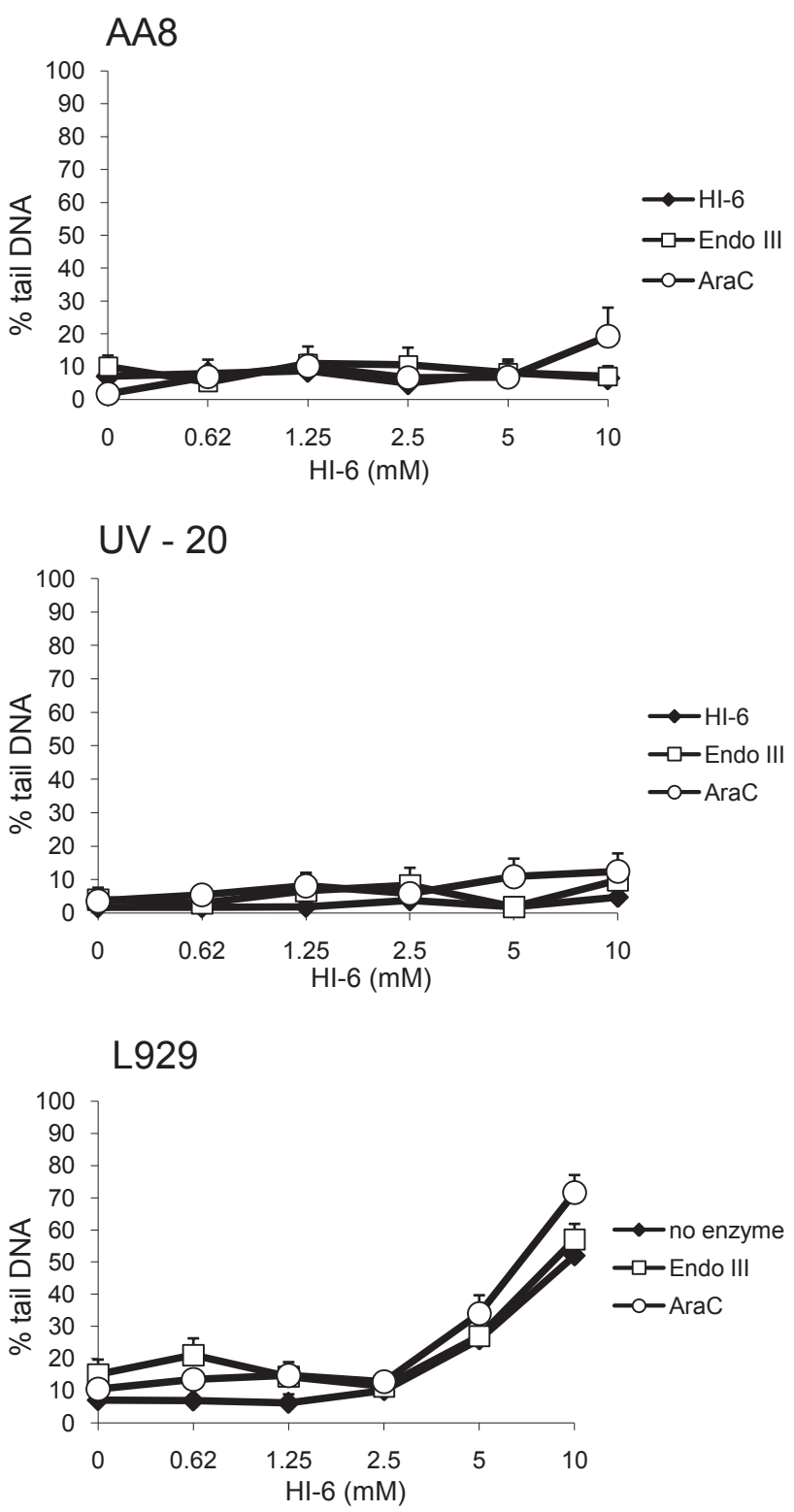

Figure 4. DNA damage induction in rodent cell lines treated with HI-6 oxime. See the legend in Fig. 3 for detailes.

other oximes tested) is not cytotoxic at concentrations up to $0.8 \mathrm{mM}$. This is in accordance with our findings shown in the present study.

Recently Radić et al. (2007) published a paper describing HI-6 effects in more detail. A variety of assays were used: alkaline comet assay, DNA diffusion assay, analysis of structural chromosome aberrations and cytochalasin-block micronucleus assay. The results showed a low cytotoxicity of HI-6 in concentrations tested (up to $0.8 \mathrm{mM}$ ). HI-6 induced neither a significant DNA damage, nor a significant increase of chromosomal damage in human peripheral blood lymphocytes. The frequency of MN in lymphocytes treated with HI-6 was not significantly increased. However, HI-6 retarded lymphocytes proliferation in vitro at the high concentration $0.42 \mathrm{mM}$. Authors did not test cytotoxicity in really cytotoxic concentrations, so that $\mathrm{IC}_{50}$ concentration could not be estimated.

Current OECD (2004) guidelines for genotoxicity testing in mammalian cells require that the highest concentration with soluble and non-toxic substances should be $10 \mathrm{mM}$. However, the suitability of using such high concentration for testing is discussed, particularly from the point of view of false positive results caused by cytotoxic concentrations (Kirkland et al. 2007). As it was recommended by the authors, we have correlated the genotoxic effect seen both on human and rodent cell lines to two endpoints of cytotoxicity, i.e. to colony forming capacity and to mitochondrial function (MTT test). In regard to induction of DNA breaks, results were obtained after $2 \mathrm{~h}$ of treatment, when the MTT test did not show significant toxicity up to $5 \mathrm{mM}$ concentration of HI-6.

In our study we have used concentrations up to $10 \mathrm{mM}$ and therefore we were able to find cytotoxic concentrations. This concerns both the colony-forming assay and the MTT test. $\mathrm{IC}_{50}$ concentrations evaluating by the colony-forming assay showed that there is no big difference in cytotoxicity among cell lines tested. Both human and rodent cells showed similar inhibition of colonies, the $\mathrm{IC}_{50}$ values varying from 1.14 to $1.7 \mathrm{mM}$, with exception of HeLa cells ( $\mathrm{IC}_{50} 3.6 \mathrm{mM}$ ) and L929 (IC $505.2 \mathrm{mM}$ ). In the case of URO and L929 at the $2.5 \mathrm{mM}$ concentration of oxime we have found lower toxicity compared to lower concentation $0.3 \mathrm{mM}$. Besides the possible influence of an experimental error, the increase of the cell viability at $2.5 \mathrm{mM}$ compared to lower concentrations of HI-6 may result from the different stability of more concentrated HI-6 in the culture medium during the $24 \mathrm{~h}$ treatment at $37^{\circ} \mathrm{C}$. As it was described by Eyer et al. (1986), at pH 7.4 HI- 6 releases up to $60 \%$ of hydrocyanic acid $(\mathrm{t} / 2=12 \mathrm{~h})$ and so considerable amounts of cyanide may be formed.

Quite interesting were results of experiments showing dependence of cytotoxic effect on time evaluated by the MTT test in A549 cells. The cytotoxic effect measured by the MTT test (measuring the activity of succinyl dehydrogenase) was increased slowly. Only $10 \mathrm{mM}$ concentration of HI- 6 reduced viability of cells significantly by $20 \%$ within $2 \mathrm{~h}$ of the treatment. In cultures incubated in the presence of 1.25-10 $\mathrm{mM} \mathrm{HI}-6$ for $72 \mathrm{~h}$ the proportion of viable cells decreased approximately to one half compared to the proportion of viable cells found after 24 or $48 \mathrm{~h}$ of incubation.

In contrast to the paper of Radić et al. (2007), who did not find any significant induction of DNA breaks in human white blood cells treated with HI-6, in our study we have observed a significant induction of DNA damage in human cell lines HepG2, UROtse, and in mouse L929 cells. The DNA damage was found in cultures treated with high concentrations of HI-6 
( 5 or $10 \mathrm{mM}$ ) already after $2 \mathrm{~h}$ of the treatment, when apoptosis could not take place. As we can guess from the results of measuring cell viability by the MTT test, there was no decrease of cell viability (at least in A549 cells) in cells treated up to 5 $\mathrm{mM}$ concentration of HI- 6 within $2 \mathrm{~h}$. This indicates that there was no cell necrosis induced within the $2 \mathrm{~h}$-treatment which might cause DNA degradation. So we have supposed that HI-6 induced alkali-labile sites (or true DNA breaks). A possibility cannot be excluded that HI-6 can induce oxidative stress (and thus also oxidative damage to DNA) (Pohanka et al. 2009). For this reason we have tried to detect oxidative DNA damage using incubation of cells lysed in the gel during the comet assay with endonuclease III according to Collins et al. (1996). Using this technique, we have not found any increase of DNA breaks in cells incubated in gel with endonuclease III, which indicates that the induced DNA damage most probably was not the oxidative one. The observed increase of the DNA damage in some cells is low and, to our experience (Collins et al. 1996), it does not correspond to the increase found in cells containing a significant amount of oxidized bases in their DNA.

From described above, we suggest that HI-6 or its metabolite(s) could be responsible for DNA damage induction. Because we did not find DNA damage induction in all cells lines tested, we may speculate that a metabolite is more probable inducer of the damage rather than the unchanged HI-6. It was described, that in rats in vivo HI-6 is excreted quite quickly by the urine within few hours, but it is partly metabolized (Ecobichon et al. 1987; Ligtenstein et al. 1990). Therefore, it cannot be excluded, that in UROtse, L929 and especially in HepG2 cells, which are known to be equipped with Cyp450 activities (Knasmüller et al. 1998), the DNA damage is induced by some of known, or unknown metabolites.

We have chosen UV-20 cells to follow the possible induction of DNA damage. This cell line is a mutant deficient in nucleotide excision repair (Thompson et al. 1981). If HI-6 would induce an alkali-labile adduct repaired by NER, then UV-20 would be markedly more sensitive to cytotoxic effect of HI-6, and it would accumulate alkali-labile sites in the DNA due to DNA repair-deficiency. However, survival measured by colony forming assay did not show any difference between normal AA8 cells and DNA repair-defective mutant UV-20 treated with HI-6. Because we did not see any significant amount of DNA damage induced with HI-6 neither in UV-20 mutant nor in parental AA8 cells, it is possible that these Chinese hamster cells do not metabolize HI-6 like HepG2, URO or L929 cells and therefore no DNA damage is induced by HI- 6 .

If HI- 6 would induce an alkali-stable DNA adduct, it would not had been detected by simple alkaline version of the comet assay used in this study and in the study of Radic et al. (2007). To exclude this possibility, in parallel cultures AraC and HU (see Materials and Methods for details) were added in the culture medium during the $2 \mathrm{~h}$ of treatment with HI- 6 .
In the presence of $\mathrm{AraC}$ and $\mathrm{HU}$ the polymerisation phase of NER is blocked so that the repaired sites remain like open gaps, that are detected as real breaks under alkaline conditions (Collins et al. 1984). However, we have not found any accumulation of repair gaps in parallel cultures containing in medium AraC and HU additionally to HI-6. This result highly indicates that there was no DNA damage in treated cells on which NER would have been acting.

This paper brings new findings concerning HI-6 cytotoxicity/genotoxicity. Results show, that cytotoxicity of HI-6 is relatively low and that there is only a very low DNA damage induced in treated cells. Results are in accordance with findings of Radić et al. (2007), who did not find significant induction of the DNA damage in human leukocytes treated with HI-6. Čalić et al. (2006) has used several cell lines (including HepG2 and CHO cells) additionally to human lymphocytes for the cytotoxicity studies. However, thanks to the low concentrations (up to $0.8 \mathrm{mM}$ ) of HI- 6 and to the short time of treatment used (up to $4 \mathrm{~h}$ ) they did not see any significant toxicity in any of tested cell types. According to our results presented in this paper cytotoxicity of HI- 6 and possible induction of DNA damage may appear in cells exposed to concentrations higher the 1-2 mM. This concentration is hardly achievable in organism exposed to therapeutic doses of HI-6. Simons and Briggs (1985) described the plasma concentration of HI- 6 as high as $0.4 \mathrm{mM}$ at $3 \mathrm{~min}$ after i.v. application. A possibility remains, that higher concentrations may appear in urine, for instance. The rapid excretion of the HI- 6 and its metabolites by urine is well known (Cassel et al. 1997) and so the high concentration in urine might represent a possible risk from the point of view of the damage of cells in urinary tract. Taking into an account possibility, that cells of the urinary tract might be more sensitive to the HI-6 toxic effect, which was found in the present study, we think this risk for the urinary tract should not be underestimated. The higher sensitivity of HepG2 cells to DNA damage induction by HI-6 may also suggests that hepatocytes may be at higher risk due to the metabolites formed in them.

Acknowledgement. Authors thank to Ms. Vera Skrancova for skilful technical assistance. The study was supported by Ministry of Defence of the Czech Republic, project No. OVUOFVZ200810.

\section{References}

Čalic B., Vrdoljak A. L., Radic B., Jelič D., Jun D., Kuča K., Kovarik Z. (2006): In vitro and in vivo evaluation of pyridinium oximes: Mode of interaction with acetylcholinesterase, effect on tabun- and soman-poisoned mice and their cytotoxicity. Toxicology 219, 85-96 http://dx.doi.org/10.1016/j.tox.2005.11.003 
Cassel G., Kalsson L., Waara L., Ang K. W., Göransson-Nyberg A. (1997): Pharmacokinetics and effects of HI-6 in blood and brain of soman-intoxicated rats: A microdialysis study. Eur. J. Pharmacol. 332, 43-52 http://dx.doi.org/10.1016/S0014-2999(97)01058-3

Collins A. R., Dobson V. L., Dušinská M., Kennedy G., Štětina R. (1997): The comet assay: what can really tell us? Mutat. Res. 375, 183-194 http://dx.doi.org/10.1016/S0027-5107(97)00013-4

Collins A. R., Dušinská M., Gedik C. M., Štětina R. (1996): Oxidative damage to DNA; do we have a reliable biomarker? Environ. Hlth. Perspect. 104 (Suppl. 3), 465-469

Collins A. R. S., Johnson R. T. (1984): The inhibition of DNA repair. Adv. Radiat. Biol. 11, 71-129

Collins A., Oscoz1 A., Brunborg G., Gaiva I., Giovannelli L., Kruszewski M., Smith, C., Štětina R. (2008): The comet assay: topical issues. Mutagenesis 23, 143-151 http://dx.doi.org/10.1093/mutage/gem051

Doetsch P. W., Henner W. D., Cunningham R. P., Toney J. H., Helland D. E. (1987): A highly conserved endonuclease activity present in Escherichia coli, bovine, and human cells recognizes oxidative DNA damage at sites of pyrimidines. Mol. Cell Biol. 7, 26- 32

Ecobichon D. J., Comeau A. M., O'Neil W. M., Marshall W. D. (1990): Kinetics, distribution, and biotransformation of the chemical HI-6 in the rat, dog, and rhesus monkey. Can. J. Physiol. Pharmacol. 68, 614-621 http://dx.doi.org/10.1139/y90-089

Erixon K., Ahnström G. (1979): Single-strand breaks in DNA during repair of UV-induced damage in normal human and Xeroderma pigmentosum cells as determined by alkaline DNA unwinding and hydroxyapatite chromatography. Effects of hydroxyurea, 5 -fluorodeoxyuridine and 1- $\beta$-D-arabinofuranosylcytosine on the kinetics of repair. Mutat. Res. 59, 257-271 http://dx.doi.org/10.1016/0027-5107(79)90164-7

Eyer P., Hell W., Kawan A., Klehr H. (1986): Studies on the decomposition of the oxime HI 6 in aqueous solution. Arch. Toxicol. 59, 266-271 http://dx.doi.org/10.1007/BF00290549

Kirkland D., Pfuhler S., Tweats D., Aardemad, M., Corvi, R., Darroudi, F., Elhajouji A., Glatt H., Hastwell P., Makoto H., Kasper P., Kirchner S., Lynch A., Marzinm D., Maurici D., Meunier J. R., Muller L., Nohyneko, G., Parry J., Parry E., Thybaud V., Tice R., van Benthemr J., Vanparys P., White P. (2007): How to reduce false positive results when undertaking in vitro genotoxicity testing and thus avoid unnecessary follow-up animal tests: Report of an ECVAM Workshop. Mutat. Res. 628, 31-55

Knasmüller S., Parzefall W., Sanyal R., Ecker S., Schwab C., Uhl M., Mersch-Sundermann V., Williamson G., Hietsch G., Langer T., Darroudi F., Natarajan A. T. (1998): Use of metabolically competent human hepatoma cells for the detection of mutagens and antimutagens. Mutat. Res. 402, 185-202 http://dx.doi.org/10.1016/S0027-5107(97)00297-2

Ligtenstein D. A., Wils E. R., Kossen S. P., Hulst A. G. (1987): Identification of two metabolites of the cholinesterase reactivator HI-6 isolated from rat urine. J. Pharm. Pharmacol. 39, $17-23$ http://dx.doi.org/10.1111/j.2042-7158.1987.tb07155.x

Litchfield J. T., Wilcoxon F. (1949): A simplified method of evaluating dose-effect experiments. J. Pharmacol. Exptl. Ther. 96, 99-113

Mirzayans. R., Waters R., Paterson M. C. (1988): Induction and repair of DNA strand breaks and 1-beta-D-arabinofuranosylcytosine-detectable sites in 40-75 kVp X-irradiated compared to $60 \mathrm{Co}$ gamma-irradiated human cell lines. Radiat. Res. 114, $168-85$ http://dx.doi.org/10.2307/3577153

OECD Series on Principles of Good Laboratory Practice and Compliance Monitoring. No. 14 on the Application of the Principles of GLP to in vitro studies, 2004

Pohanka M., Zdarova Karasova J., Musilek K., Kuca K., Kassa J. (2009): Effect of five acetylcholinesterase reactivators on tabun-intoxicated rats: induction of oxidative stress versus reactivation efficacy. J. Appl. Toxicol. 29, 483-488 http://dx.doi.org/10.1002/jat.1432

Putman D., San R. H. C., Bigger A., Levine B. S., Jacobson-Kram D. (1996): Genetic Toxicology assessment of HI-6 dichloride. Environ. Mol. Mutagen. 27, 152-161 http://dx.doi.org/10.1002/(SICI)1098-2280(1996)27:2<152:: AID-EM9>3.0.CO;2-I

Radić B., Vrdoljak A. L., Želježić D., Fuchs N., Berend S., Kopjar N. (2007): Evaluation of HI-6 oxime: potential use in protection of human acetylcholinesterase inhibited by antineoplastic drug irinotecan and its cyto/genotoxicity in vitro. Acta Biochim. Pol. 54, 583-593

Rossi M. R., Masters J. R. W., Park S., Todd J. H., Garrett S. H., Sens M. A., Somji S., Nath J., Sens D. A. (2001): The immortallized UROtsa cell line as a potential cell culture model of human urothelium. Environ. Hlth. Perspect. 109, 801-808 http://dx.doi.org/10.1289/ehp.01109801

Squires S., Johnson R. T., Collins A. R. S. (1982): Initial rates of DNA incision in UV-irradiated human cells. Differences between normal Xeroderma pigmentosum and tumour cells. Mutat. Res. 95, 389-404 http://dx.doi.org/10.1016/0027-5107(82)90273-1

Thompson L. H., Busch D. B., Brookman K., Mooney C. L., Glaser A. (1981): Genetic diversity of UV-sensitive DNA repair mutants of Chinese hamster ovary cells. Proc. Natl. Acad. Sci. U.S.A. 78, 3734-3737 http://dx.doi.org/10.1073/pnas.78.6.3734

Trivedi A. B., Kitabatake N., Doi E. (1990): Toxicity of dimethyl sulfoxide as a solvent in bioassay system with HeLa cells evaluated colorimetrically with 3-(4,5-dimethyl thiazol-2-yl)-2,5-diphenyltetrazolium bromide. Agric. Biol. Chem. 54, 2961-2966 http://dx.doi.org/10.1271/bbb1961.54.2961

Vrdoljak A. L., Berend S., Zeljezić D., Piljac-Zegarac J., Plestina S., Kuca K., Radić B., Mladinić M., Kopjar N. (2009): Irinotecan side effects relieved by the use of HI-6 oxime: in vivo experimental approach. Basic Clin. Pharmacol. Toxicol. 105, 401-409

http://dx.doi.org/10.1111/j.1742-7843.2009.00460.x

Received: November 4, 2011

Final version accepted: December 6, 2011 